\title{
Isolation of an aerobic sulfur oxidizer from the SUP05/Arctic96BD-19 clade
}

\author{
Katharine T Marshall and Robert M Morris \\ School of Oceanography, University of Washington, Seattle, WA, USA
}

\begin{abstract}
Bacteria from the uncultured SUP05/Arctic96BD-19 clade of gamma proteobacterial sulfur oxidizers (GSOs) have the genetic potential to oxidize reduced sulfur and fix carbon in the tissues of clams and mussels, in oxygen minimum zones and throughout the deep ocean ( $>200 \mathrm{~m})$. Here, we report isolation of the first cultured representative from this GSO clade. Closely related cultures were obtained from surface waters in Puget Sound and from the deep chlorophyll maximum in the North Pacific gyre. Pure cultures grow aerobically on natural seawater media, oxidize sulfur, and reach higher final cell densities when glucose and thiosulfate are added to the media. This suggests that aerobic sulfur oxidation enhances organic carbon utilization in the oceans. The first isolate from the SUP05/Arctic96BD-19 clade was given the provisional taxonomic assignment 'Candidatus: Thioglobus singularis', alluding to the clade's known role in sulfur oxidation and the isolate's planktonic lifestyle.
\end{abstract}

The ISME Journal (2013) 7, 452-455; doi:10.1038/ismej.2012.78; published online 9 August 2012

Subject Category: microbial ecology and functional diversity of natural habitats

Keywords: cultivation; GSO; Arctic96BD-19; SUP05; sulfur

\section{Introduction}

Marine sulfur-oxidizing bacteria thrive in lowoxygen environments. They have critical roles in the production of organic matter using energy derived from hydrogen sulfide that is produced by sulfate-reducing bacteria or leached from the ocean crust at high temperatures (Sievert et al., 2007). The reduced sulfur in hydrogen sulfide has an oxidation state of -2 and is available as an energy source for anaerobic bacteria that oxidize sulfide by reducing nitrate to nitrogen gas, nitrous oxide or ammonia. Less is known about sulfur oxidation in oxygenated marine waters. There were hints in the 1970s that this was an important process. Tuttle and Jannasch (1976, 1977) identified bacteria capable of oxidizing thiosulfate in diverse inshore and offshore waters and demonstrated the potential for thiosulfate oxidation to enhance carbon fixation and glucose utilization. More recently, Swan et al. (2011) identified genes for sulfur oxidation, carbon fixation and organic matter transport in the SUP05/Arctic96BD-19 clade of gamma proteobacterial sulfur oxidizers (GSOs) from oxygenated waters in the dark ocean.

The SUP05/Arctic96BD-19 clade of marine GSOs is comprised of symbiotic and planktonic

Correspondence: RM Morris, School of Oceanography, University of Washington, Seattle, WA 98195, USA.

E-mail: morrisrm@uw.edu

Received 10 April 2012; revised 4 June 2012; accepted 7 June 2012; published online 9 August 2012 representatives from the 'Basal' group of gamma proteobacteria, which contains the most ancient and highly diverged lineages of gamma proteobacteria (Williams et al., 2010). Here, we report isolation and thiosulfate enhanced heterotrophic growth of the first pure culture representative from the SUP05/ Arctic96BD-19 clade of GSOs (Supplementary Methods). Several planktonic strains were cultured from surface waters in Puget Sound in November $2009(n=3)$ and from the deep chlorophyll maximum in the North Pacific gyre in $2011(n=5$; Supplemental Table 1). The presence of viable cells at diverse sites in the North Pacific suggests that active members of this clade are widely distributed in the ocean surface layer. A representative strain was revived and purity was verified by observing a single 16S rRNA gene fragment in successive cultures and imaging cells with an isolate-specific fluorescence in situ hybridization probe (Supplementary Figure 1).

\section{Results and discussion}

Cultured SUP05/Arctic96BD-19 cells are extremely small and produce extracellular globules (Figure 1). The potential for sulfur oxidation was confirmed by identifying sulfur $\left(\mathrm{S}^{\circ}\right)$ in the extracellular globules using scanning transmission electron microscopy (Figure 1a) combined with energy-dispersive X-ray spectroscopy (Figures $1 \mathrm{~b}$ and c). These data support the genomic findings of Walsh et al. (2009), which 
a

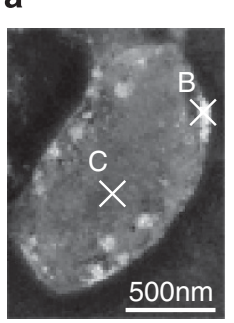

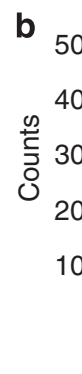
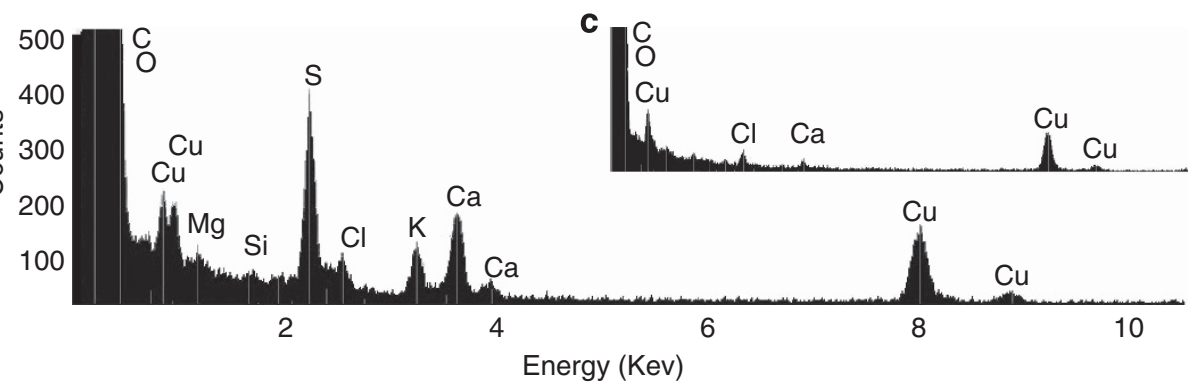

Figure 1 Image of Candidatus Thioglobus singularis and evidence of sulfur globules determined by scanning transmission electron microscopy combined with energy dispersive X-ray spectroscopy (STEM-EDX). (a) STEM image and (b and c) EDX profiles. White extracellular globules contain sulfur (b) that was not detected in parts of the cell with no globule (c). Samples were analyzed on a copper $(\mathrm{Cu})$ grid.

suggested that members of this clade have the capacity to oxidize and store $\mathrm{S}^{\circ}$ due to an incomplete Sox pathway. Suspected roles in marine carbon and sulfur cycles were further evaluated using previously published PCR primers or new primers targeting genes involved in carbon fixation and sulfur oxidation (Blazejak et al., 2006; Swan et al., 2011). Of the primer pairs tried, only the dissimilatory aprA gene was identified (Hipp et al., 1997; Kelly et al., 1997; Friedrich et al., 2005; Blazejak et al., 2006). The inability to amplify carbon fixation genes using degenerate primers suggests that cultured GSOs are significantly diverged from known GSOs that occupy anoxic zones and the deep ocean (Walsh et al., 2009; Swan et al., 2011) or that they get all of their carbon from organic compounds.

Sulfur-oxidizing bacteria capable of heterotrophy are well known. They are found in diverse lineages, including alpha and gamma proteobacteria and the Cytophaga-Flavobacterium-Bacteroides group (Teske et al., 2000) and some marine Firmicutes. The gamma proteobacteria include Pseudomonads, Pseudoalteromonas and Halomonas-Deleya (Tuttle et al., 1974; Teske et al., 2000). These lineages (along with epsilon proteobacteria) are common at hydrothermal vents and at oxic/anoxic interfaces, where reduced sulfur compounds are used to produce energy (Tuttle et al., 1974; Ruby et al., 1981; Durand et al., 1994; Teske et al., 2000; Sorokin, 2003; Podgorsek et al., 2004). Sulfur oxidation enables these bacteria to use more organic carbon for biosynthesis and less for respiration, giving them the ability to compete in a wide range of marine habitats (Teske et al., 2000; Podgorsek et al., 2004).

The marine sulfate reservoir has increased over the last $0.5-2.5$ billion years, to its current concentration of $28 \mathrm{~mm}$ (Canfield et al., 2000). Relative to sulfate, there is little to no accumulation of the inorganic sulfur cycle intermediates thiosulfate and tetrathionate, which suggests that ubiquitous sulfuroxidizing marine bacteria oxidize these compounds in seawater. We evaluated thiosulfate as a potential energy source for heterotrophic growth on glucose (Supplementary Methods). Thiosulfate is ubiquitous at low concentrations in seawater $(<5 \mu \mathrm{M})$ and is relatively stable in the presence of oxygen (Hayes et al., 2006). Thiosulfate enhanced heterotrophic glucose utilization (Figure 2). Growth rates and final cell densities increased when glucose alone was added to the media and were highest when both glucose and thiosulfate were added to the media (Figures 2a and b, respectively). It is unlikely that this is due to co-limitation of carbon and sulfur because increasing concentrations of glucose alone increased cell densities. Cell densities at each concentration of glucose also increased when thiosulfate was also added to the media, and sulfur globules are only produced by sulfuroxidizing organisms. Combined, these data suggest that energy derived from sulfur oxidation can enhance organic carbon turnover in the oxygenated ocean.

\section{Conclusion}

We propose the provisional taxonomic assignment 'Candidatus: Thioglobus singularis', alluding to the clade's known role in sulfur oxidation and the Isolate's planktonic lifestyle.

Thioglobus gen. nov.

Thioglobus singularis sp. nov.

Etymology. thios (Gr. noun): sulfur, globus (L. masc. noun): ball, sphere, globe. Singularis (L. adj.): alone, singular. The Genus name alludes to the clade's ability to oxidize sulfur and to the sulfur globules found on the outside of the cells. The species name alludes to the fact that this is a free-living member of the clade, rather than a symbiont.

Locality: surface waters in Puget Sound.

Diagnosis: a small mesophilic sulfur oxidizer from the gamma proteobacteria.

Accession numbers deposited in public databases Gene sequences were assigned the following NCBI accession numbers; Puget Sound cultures, 16S rRNA genes (JQ254014-JQ254058); North Pacific 



Figure 2 Growth rates and cell densities of Candidatus Thioglobus singularis. All experimental treatments were conducted in six replicate cultures and growth was plotted following initial detection $\left(10^{4} \mathrm{cells} \mathrm{ml}^{-1}\right)$. (a) Growth rates with glucose and glucose plus thiosulfate added to the media. (b) Final cell densities with glucose and glucose plus thiosulfate added to the media. Media was amended with $1 \mu \mathrm{M}, 10 \mu \mathrm{M}$ or $100 \mu \mathrm{M}$ glucose and each concentration of glucose plus $1 \mathrm{~mm}$ thiosulfate.

gyre cultures, 16S rRNA genes (JQ253970JQ254013); SUP05/Arctic96BD-19 isolate, Puget Sound isolate 16S rRNA gene (JN003574); SUP05/ Arctic96BD-19 isolate, North Pacific gyre isolate 16S rRNA gene (JQ253969) and Puget Sound isolate aprA gene (JQ253968). Cultures will be provided upon request.

\section{Acknowledgements}

We thank the captain, officers and crew of the $R V$ Thompson for their assistance during 2009 and 2011 cruises. This work was supported by the University of Washington, School of Oceanography, a grant from the National Science Foundation (OCE-0723866) and the Pacific Northwest Center for Human Health and Ocean Sciences (National Institute of Environmental Health: P50 ES012762 and National Science Foundation: OCE0434087). We also thank V Iverson for help implementing a culture classification strategy.

\section{References}

Blazejak A, Kuever J, Erseus C, Amann R, Dubilier N. (2006). Phylogeny of $16 \mathrm{~S}$ rRNA, ribulose 1,5-bisphosphate carboxylase/oxygenase, and adenosine $5^{\prime}$ phosphosulfate reductase genes from gamma- and alphaproteobacterial symbionts in gutless marine worms (oligochaeta) from Bermuda and the Bahamas. Appl Environ Microbiol 72: 5527-5536.

Canfield DE, Habicht KS, Thamdrup B. (2000). The archean sulfur cycle and the early history of atmospheric oxygen. Science 288: 658-661.

Durand P, Benyagoub A, Prieur D. (1994). Numerical taxonomy of heterotrophic sulfur-oxidizing bacteria isolated from southwestern Pacific hydrothermal vents. Can J Microbiol 40: 690-697.

Friedrich CG, Bardischewsky F, Rother D, Quentmeier A, Fischer J. (2005). Prokaryotic sulfur oxidation. Curr Opin Microbiol 8: 253-259.

Hayes MK, Taylor GT, Astor Y, Scranton MI. (2006). Vertical distributions of thiosulfate and sulfite in the Cariaco Basin. Limnol Oceanogr 51: 280-287.

Hipp WM, Pott AS, Thum-Schmitz N, Faath I, Dahl C, Truper HG. (1997). Towards the phylogeny of APS reductases ad sirohaem sulfite reductases in sulfatereducing and sulfur-oxidizing prokaryotes. Microbiol 143: 2891-2902.

Kelly DP, Shergill JK, Lu WP, Wood AP. (1997). Oxidative metabolism of inorganic sulfur compounds by bacteria. A Van Leeuw J 71: 95-107.

Podgorsek L, Petri R, Imhoff JF. (2004). Cultured and genetic diversity, and activities of sulfuroxidizing bacteria in low-temperature hydrothermal fluids of the North Fiji Basin. Mar Ecol Prog Ser 266: 65-76.

Ruby EG, Wirsen CO, Jannasch HW. (1981). Chemolithotrophic sulfur-oxidizing bacteria from the Galapagos rift hydrothermal vents. Appl Environ Microb 42: 317-324.

Teske A, Brinkhoff T, Muyzer G, Moser DP, Rethmeier J, Jannasch HW. (2000). Diversity of thiosulfate-oxidizing bacteria from marine sediments and hydrothermal vents. Appl Environ Microbiol 66: 3125-3133.

Tuttle JH, Holmes PE, Jannasch HW. (1974). Growth rate stimulation of marine pseudomonads by thiosulfate. Arch Microbiol 99: 1-14.

Tuttle JH, Jannasch HW. (1976). Microbial utilization of thiosulfate in the deep sea. Limnol Oceanogr 21: 697-701.

Tuttle JH, Jannasch HW. (1977). Thiosulfate stimulation of microbial dark assimilation of carbon dioxide in shallow marine environments. Microb Ecol 4: 9-25.

Sievert SM, Kiene RP, Schultz-Vogt HN. (2007). The sulfur cycle. Oceanography 20: 117-123. 
Sorokin DY. (2003). Oxidation of inorganic sulfur compounds by obligately organotrophic bacteria. Microbiol 72: 641-653.

Swan BK, Martinez-Garcia M, Preston CM, Sczyrba A, Woyke T, Lamy D et al. (2011). Potential for chemolithoautotrophy among ubiquitous bacteria lineages in the dark ocean. Science 333: 1296-1300.
Walsh DA, Zaikova E, Howes CG, Song YC, Wright JJ, Tringe SG et al. (2009). Metagenome of a versatile chemolithoautotroph from expanding oceanic dead zones. Science 326: 578-582.

Williams KP, Gillespie JJ, Sobral WS, Nordberg EK, Snyder EE, Shallom JM et al. (2010). Phylogeny of gammaproteobacteria. J Bacteriol 192: 2305-2314.

Supplementary Information accompanies the paper on The ISME Journal website (http://www.nature.com/ismej) 